\title{
A Hetero-Diels-Alder Approach to Complex Pyrones: An Improved Synthesis of the Spongistatin AB Spiroketal
}

\author{
Michael T. Crimmins ${ }^{*}$ and Aaron C. Smith \\ Venable and Kenan Laboratories of Chemistry, University of North Carolina at Chapel Hill, Chapel \\ Hill, North Carolina, 27599
}

\begin{abstract}

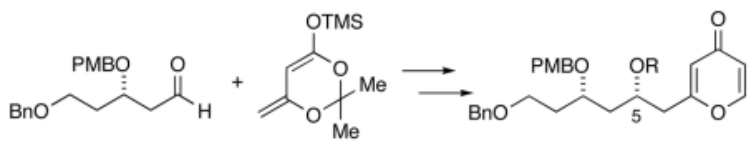

The conversion of a substituted dioxinone to a pyrone was used in an improved synthesis of the $A B$ spiroketal subunit of the spongistatins. This transformation occurred via a hetero-Diels-Alder reaction of an acyl ketene with butyl vinyl ether. A double diastereoselective Mukaiyama aldol reaction is used to provide the hetero-Diels-Alder precursor.
\end{abstract}

The spongistatins (Figure 1) are potent antitumor agents ${ }^{1}$ initially isolated in 1993 from marine sponges of the genus Spongia. ${ }^{2}$ The potenial clinical importance of the spongistatins has created substantial interest in their synthesis, and several total syntheses have been accomplished. ${ }^{3}$ The total synthesis of spongistatins 1 and $2(\mathbf{1}, \mathbf{2})$ from our laboratory was based on the assembly of three fragments including the $\mathrm{C} 1-13 \mathrm{AB}$ spiroketal 3 (Figure 1). ${ }^{4}$

Our original synthesis of the AB spiroketal (Scheme 1) centered on the preparation of pyrone 4 through addition of a metallated pyrone to an aldehyde. As shown in Scheme 1, deprotonation of pyrone $\mathbf{5}$ with LiHMDS followed by addition of aldehyde $\mathbf{6}$ led to the generation of a 1:1 mixture of diastereomers. All attempts to improve the diastereoselection of the addition by changing the counterion, solvents and additives were unsatisfactory. ${ }^{5}$ Additionally, attempts to prepare the enol silyl ether of pyrone 5 to investigate Mukaiyama type additions to aldehyde $\mathbf{6}$ were thwarted since all silylating conditions led to C-silylation of pyrone $\mathbf{5}$. The lack of stereocontrol at $\mathrm{C} 5$ required a four-step sequence to correct and could not be accomplished until after the spiroketalization event, thus requiring that both diastereomers be carried forward several steps prior to convergence. An improvement in the preparation of the pyrone precursor to the spiroketal which overcomes this stereochemical shortcoming is reported herein.

Retrosynthetically, the $\mathrm{AB}$ spiroketal subunit was envisioned to come from an acid-catalyzed cyclization ${ }^{6}$ of pyrone 9 (Scheme 2 ), which would be formed through a hetero-Diels-Alder cycloaddition-elimination sequence from dioxinone 10. The dioxinone would derive from a selective Mukaiyama aldol addition of silyl dienolate $\mathbf{1 1}$ to aldehyde $\mathbf{6}$.

To improve the synthesis of the $\mathrm{AB}$ spiroketal, a general method to selectively access the Mukaiyama aldol adduct of silyl dienolate $\mathbf{1 1}$ with aldehyde $\mathbf{6}$ was needed. First attempts to achieve this goal focused on the use of different Lewis acids to take advantage of the potential directing ability of the $\beta$-alkoxyaldehyde. The use of a common Lewis acid, $\mathrm{BF}_{3}-\mathrm{OEt}_{2}$ (Table 
1, entry 1), proved nonselective, albeit high yielding. We next investigated the use of stronger chelating Lewis acids, such as $\mathrm{Me}_{2} \mathrm{AlCl}$ (entry 2), which has been used in similar casesto achieve rigid chelating transition states with $\beta$-alkoxyaldehydes and addition of silyl enol ethers leading to high anti selectivity. ${ }^{7}$ Unfortunately, only a slight preference (1.3:1) in favor of the anti diastereomer was observed. The use of titanium Lewis acids (entries 3-7) slightly improved the anti selectivity, but the best case with titanium(IV) dichlorodiisopropoxide (entry 6) provided only a 3.3:1 preference for the anti diastereomer.

Chiral ligands were then explored in an attempt to use reagent control to influence the diastereoselectivity of the reaction. BINOL in conjunction with $\mathrm{Ti}(i-\mathrm{PrO})_{4}$ has been reported to result in good selectivity in Mukaiyama aldol additions, ${ }^{8}$ but when applied to the case at hand (entry 8), low yield and poor selectivity were observed. TADDOL has also been shown to provide high levels of reagent conrol in Lewis acid catalyzed aldol additions. ${ }^{9}$ Exposure of dienolate 11 and aldehyde $\mathbf{6}$ to titanium(IV) dichlorodiisopropoxide and $S, S$-TADDOL (entry 9 ) delivered a 5:1 mixture favoring the anti diastereomer. Unfortunately, $R, R$-TADDOL gave only a 2:1 preference for the syn diastereomer (entry 10).

Satisfactory diastereoselection was ultimately obtained taking advantage of Carreira's catalyst, 10 which has been reported to effect enantioselective Mukiayama aldol additions of silyl dienolate $\mathbf{1 1}$ with a variety of achiral aldehydes. Use of the Carreira protocol with dienolate 11 and aldehyde 6, allowed access to either the syn diastereomer 12s or anti diastereomer 12a in high yield and selectivity with low catalyst loadings. Using the (+)-enantiomer of $\mathbf{1 3}$ (entry 12) led to formation of a 10:1 mixture of aldol adducts favoring the desired syn diastereomer 12s (95\% yield), while (-)-13 produced the anti diastereomer 12a (entry 11) as the major product $(8.6: 1 \mathrm{dr}, 81 \%$ yield).

Having accomplished an efficient synthesis of the desired dioxinone 12s, its conversion to the required pyrone was investigated. An extension of the method reported by Coleman and Grant ${ }^{11}$ to include more complex substrates, by performing a hetero-Diels-Alder reaction of an acyl ketene with butyl vinyl ether, was envisioned for conversion of dioxinone 12s to the desired pyrone. To this end, the C5 hydroxyl was readily protected as a benzyloxymethyl ether to provide hetero-Diels-Alder precursor 14 (Scheme 3). Heating dioxinone 14 in toluene in the presence of butyl vinyl ether led to formation of butyl acetal $\mathbf{1 6}$ presumably through a heteroDiels-Alder reaction of intermediate acyl ketene 15 with butyl vinyl ether. Immediate exposure of the butyl acetal to $p$-TsOH in THF led to rapid elimination of butanol to produce pyrone 17 (65\% over two steps). ${ }^{12}$

Efficient conversion of the dioxinone $\mathbf{1 4}$ to the butyl acetal $\mathbf{1 6}$ required that all materials be rigorously dried to avoid trapping of the acyl ketene intermediate by advantitious water. Failure to scrupulously dry the dioxinone, the solvent or butyl vinyl ether led to formation of $\beta$-keto acid 19 (Scheme 4, path a). Additionally, the choice of protecting group on the C5 hydroxyl group was critical. Early attempts to effect the hetero-Diels-Alder reaction using triethylsilyl ${ }^{13}$ and $t$-butyl dimethylsilyl ethers at $\mathrm{C} 5$ resulted in formation of $\beta$-keto lactone 20 presumably via interception of the acyl ketene by the $\mathrm{C} 5$ ether oxygen followed by loss of the labile silicon protecting group (Scheme 4 , path b) ${ }^{14}$ Incorporating the more robust benzyloxymethyl group precluded formation of the $\beta$-keto lactone $\mathbf{2 0}$.

Taking advantage of the chemistry previously employed in the total synthesis of spongistatin, the $p$-methoxybenzyl group was removed by the action of DDQ to provide the free alcohol at C3 (Scheme 5). Exposure of the hydroxypyrone to catalytic trifluoroacetic acid in benzene provided spiroenone $\mathbf{2 1}$ in $64 \%$ yield after recycle. The minor diastereomer $(<10 \%$ which had been introduced in the Mukaiyama aldol addition) could be readily removed after the spiroketalization. Treatment of the spiroenone $\mathbf{2 1}$ with the vinyl cuprate reagent formed from 
vinylmagnesium bromide and tetrakis[copper(I) iodide-tributylphosphine] led to the formation of alkene $\mathbf{2 2}$ as the major diastereomer $(5: 1 \mathrm{dr})$. The $\mathrm{C} 9$ tertiary carbinol was introduced by addition of methylmagnesium iodide to the $\mathrm{C} 9$ ketone. Cleavage of the benzyloxymethyl ether occurred upon treatment with acid to provide the desired diol 3. Comparison of spectral data confirmed the interception of the previously synthesized fragment utilized in the reported total synthesis of spongistatin. ${ }^{4}$

In summary, an improved synthesis of the $\mathrm{AB}$ spiroketal subunit of spongistatin has been developed. This synthesis takes advantage of a double diastereoselective Mukaiyama aldol reaction and subsequent hetero-Diels-Alder cycloaddition to contstruct a pyrone precursor for a spiroketalization reaction.

\section{Supplementary Material}

Refer to Web version on PubMed Central for supplementary material.

\section{Acknowledgements}

Special thanks to Professor Xumu Zhang at Pennsylvania State University for providing an enantiopure precursor to Carreira's catalyst. Financial support from the National Cancer Institute (CA63572) is gratefully acknowledged.

\section{References}

1. (a) Bai R, Cichacz ZA, Herald CL, Pettit GR, Hamel E. Mol Pharmacol 1993;44:757-66. [PubMed: 8232226] (b) Bai R, Taylor GF, Cichacz ZA, Herald CL, Kepler JA, Pettit GR, Hamel E. Biochemistry 1995;34:9714-21. [PubMed: 7626642]

2. (a) Pettit GR, Herald CL, Cichacz ZA, Gao F, Schmidt JM, Byd MR, Christie ND, Boettner FE. J Chem Soc, Chem Commun 1993:1805-7. (b) Pettit GR, Cichacz ZA, Herald CL, Gao F, Boyd MR, Schmidt JM, Hamel E, Bai R. J Chem Soc, Chem Commun 1994:1605-6. (c) Pettit GR, Cichacz ZA, Gao F, Herald CL, Boyd MR. J Chem Soc, Chem Commun 1993:1166-8. (d) Pettit GR, Chicacz ZA, Gao F, Herald CL, Boyd MR, Schmidt JM, Hooper JNA. J Org Chem 1993;58:1302-4.

3. Yeung KS, Paterson I. Chem Rev 2005;105:4237-4313. [PubMed: 16351045]For other recent synthetic efforts see: Smith AB III, Sfouggatakis C, Gotchev DB, Shirakami S, Bauer D, Zhu W, Doughty VA. Org Lett 2004;6:3637-40. [PubMed: 15387567]and refernces therein

4. (a) Crimmins MT, Katz JD, Washburn DG, Allwein SP, McAtee LF. J Am Chem Soc 2002;124:56613. [PubMed: 12010038]Crimmins MT, Katz JD, McAtee LC, Tabet EA, Kirincich SJ. Org Lett 2001;3:949-952. [PubMed: 11263923] (b) Crimmins MT, Katz JD. Org Lett 2000;2:957-60. [PubMed: 10768196] (c) Crimmins MT, Washburn DG. Tetrahedron Lett 1998;39:7487-90.

5. Crimmins MT, Washburn DG, Katz JD, Zawacki FJ. Tetrahedron Lett 1998;39:3439-42.

6. Crimmins MT, O’Mahony R. J Org Chem 1990;55:5894-900.

7. Evans DA, Allison BD, Yang MG, Masse CE. J Am Chem Soc 2001;123:10840-52. [PubMed: 11686685]

8. (a) De Rosa M, Soriente A, Scettri A. Tetrahedron: Asymmetry 2000;11:3187-95. (b) De Rosa M, Acocella MR, Soriente A, Scettri A. Tetrahedron: Asymmetry 2001;12:1529-31.

9. (a) Seebach D, Beck AK, Heckel A. Angew Chem, Int Ed 2001;40:92-138. (b) Szlosek M, Jullian JC, Hocquemiller R, Figadere B. Heterocycles 2000;52:1005-13.

10. Singer RA, Carreira EM. J Am Chem Soc 1995;117:12360-61.

11. Coleman RS, Grant EB. Tetrahedron Lett 1990;31:3677-80. see also Sato M, Ogasawara H, Kato K, Sakai M, Kato T. Chem Pharm Bull 1983;31:4300-05.

12. Zawacki FJ, Crimmins MT. Tetrahedron Lett 1996;37:6499-6502.

13. Dr. Jason D. Katz thesis, University of North Carolina

14. Sato M, Sunami S, Sugita Y, Kaneko C. Heterocycles 1995;41:1435-44.Sato M, Sunami S, Sugita Y, Kaneko C. Chem Pharm Bull 1994;42:839-45.

Org Lett. Author manuscript; available in PMC 2008 September 22. 


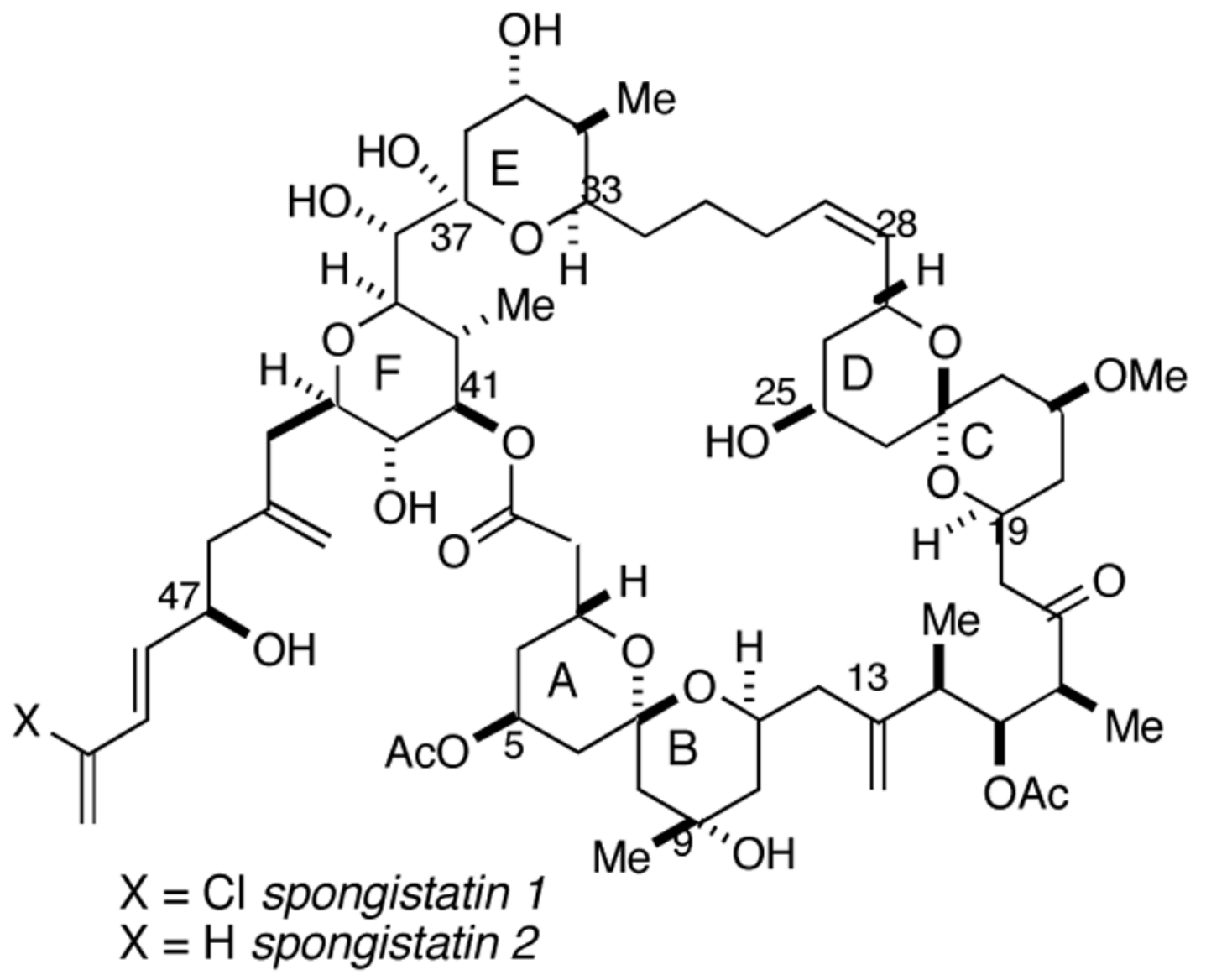

Figure 1.

The Spongistatins 


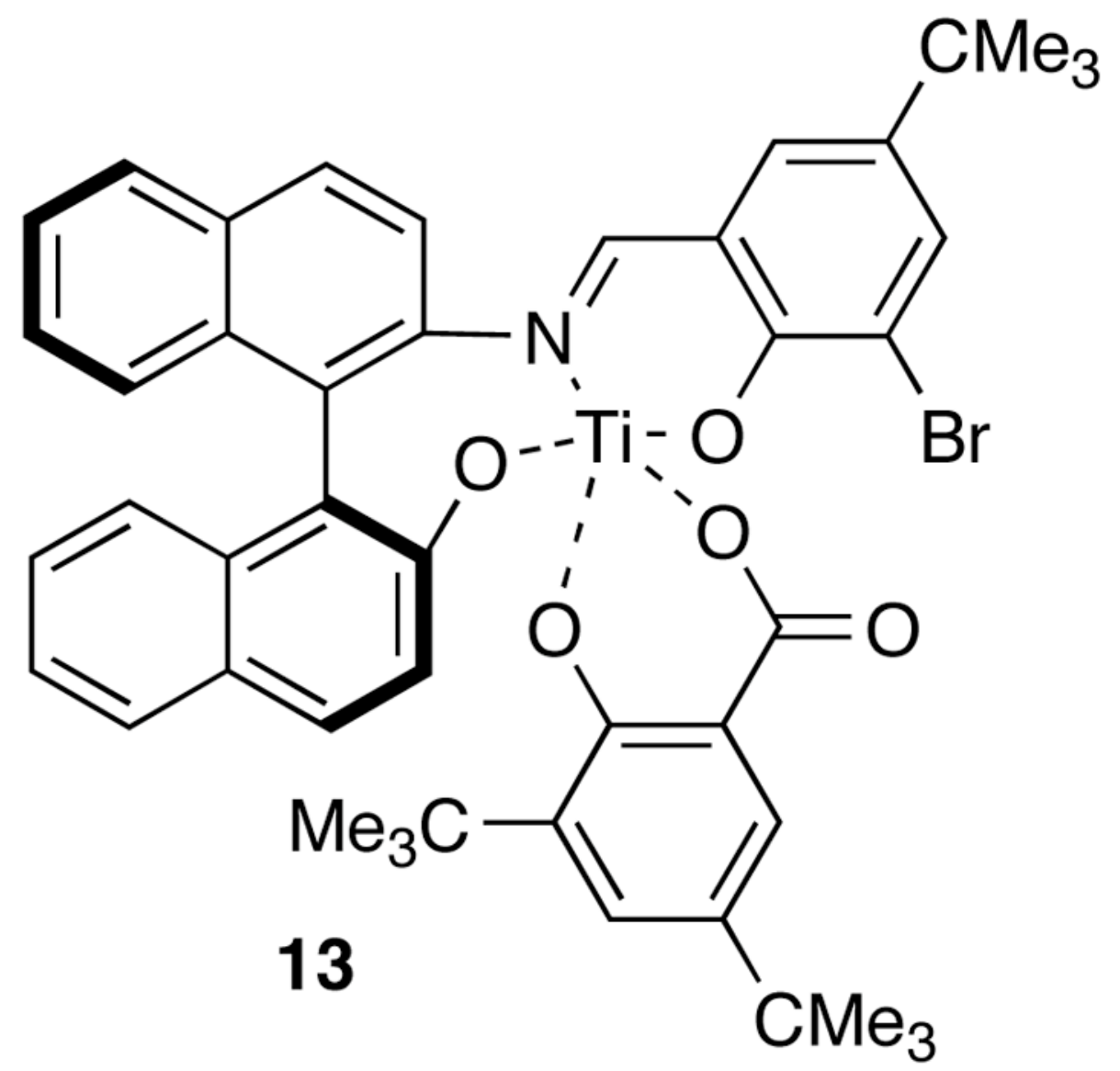

Figure 2.

Carreira's Catalyst 
<smiles>C=C[C@@H]1C[C@@](C)(O)C[C@]2(C[C@H](O)C[C@H](CCOCc3ccccc3)O2)O1</smiles><smiles>CCCCC(C)O[C@@H](CCOCc1ccccc1)C[C@@H](O)Cc1cc(=O)cco1</smiles><smiles>Cc1cc(=O)cco1</smiles><smiles>O=c1ccoc(C[C@@H](O)C[C@H](CCOc2ccccc2)OCCCCOc2ccccc2)c1</smiles>

Scheme 1.

Addition of Metallated Pyrones to Aldehydes 


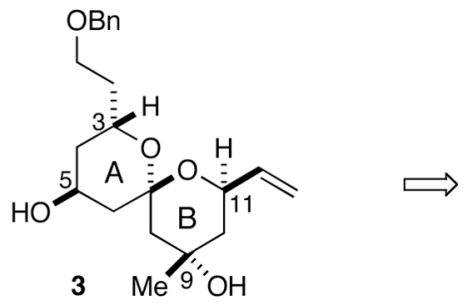<smiles>O=c1ccoc(C[C@@H](O)C[C@H](O)CCOBr)c1</smiles><smiles>C=C1C=C(O[R15](C)(C)C)OC(C)(C)O1</smiles>

Scheme 2.

Hetero-Diels-Alder Cycloaddition Strategy 


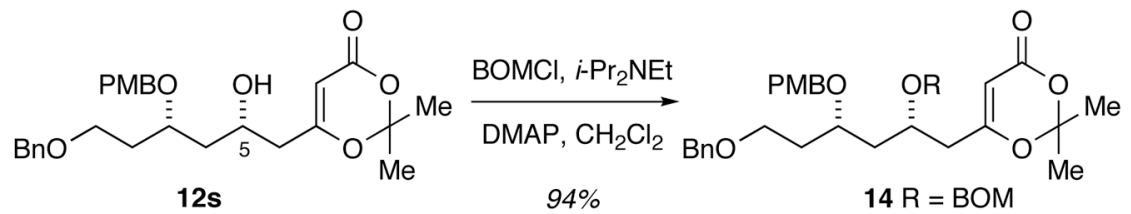<smiles>C=COC(C)CCCCC</smiles>

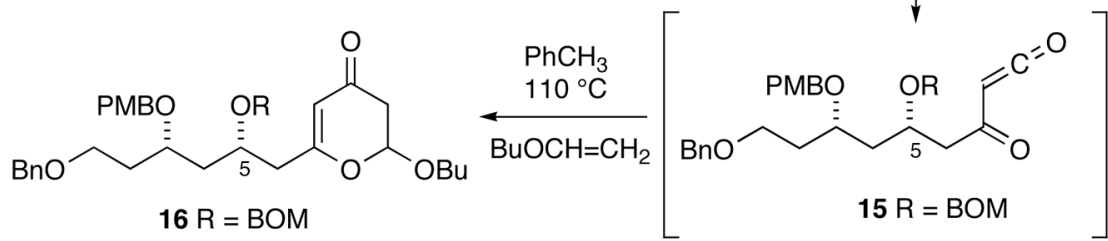

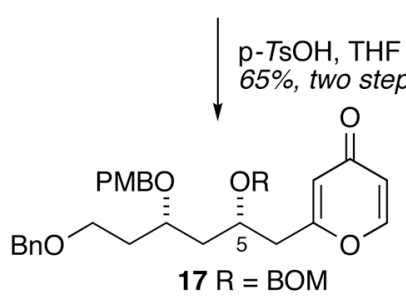

Scheme 3.

Hetero-Diels-Alder Cycloaddition 


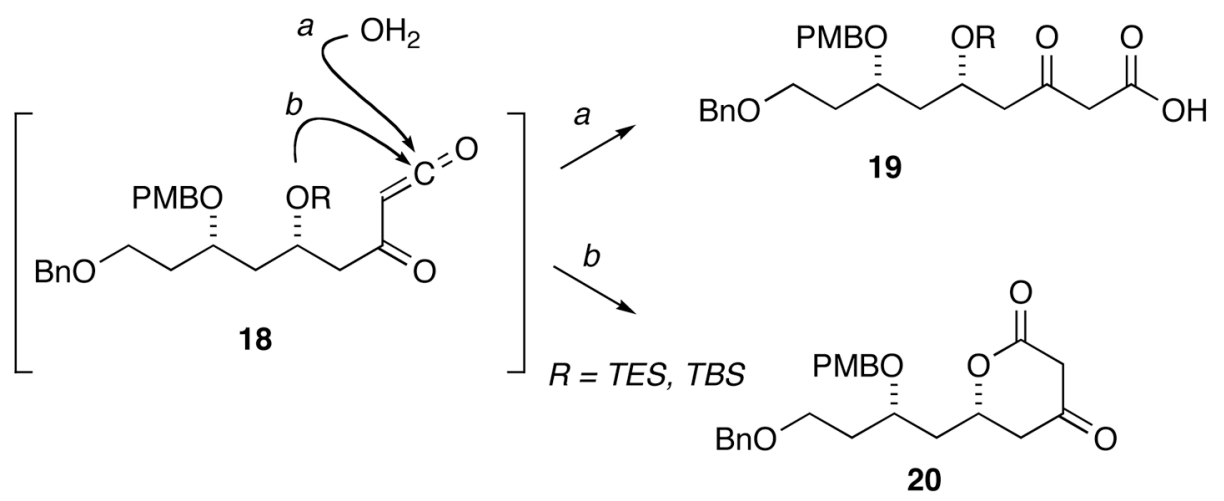

Scheme 4.

Side reactions of acyl ketene intermediate 


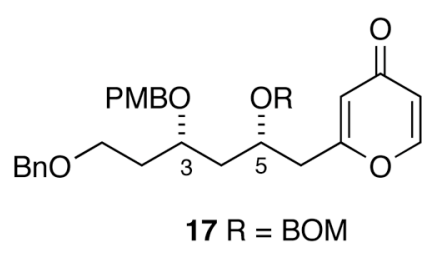

1. DDQ, pH 7 buffer

$\mathrm{CH}_{2} \mathrm{Cl}_{2}, 97 \%$

2. TFA, $\mathrm{C}_{6} \mathrm{H}_{6}, 64 \%$<smiles>CO[C@H]1C[C@@H](CCOc2ccccc2)C[C@@]2(CC(=O)C=CO2)O1</smiles>

\begin{tabular}{l|l}
$\mathrm{CH}_{2}=\mathrm{CHMgBr}$ \\
{$\left[\mathrm{Cul}-\mathrm{Bu}_{3} \mathrm{P}\right]_{4}$} \\
$\mathrm{Et}_{2} \mathrm{O},-78{ }^{\circ} \mathrm{C}$
\end{tabular}

1. MeMgl,THF, $-78^{\circ} \mathrm{C}, 73 \%$<smiles>C=C[C@H]1CC(=O)C[C@]2(C[C@@H](OC(C)OC)C[C@H](CCOCc3ccccc3)O2)O1</smiles>

Scheme 5.

Completion of AB Spiroketal 
Table 1

Use of Lewis Acids in Addition to Aldehyde

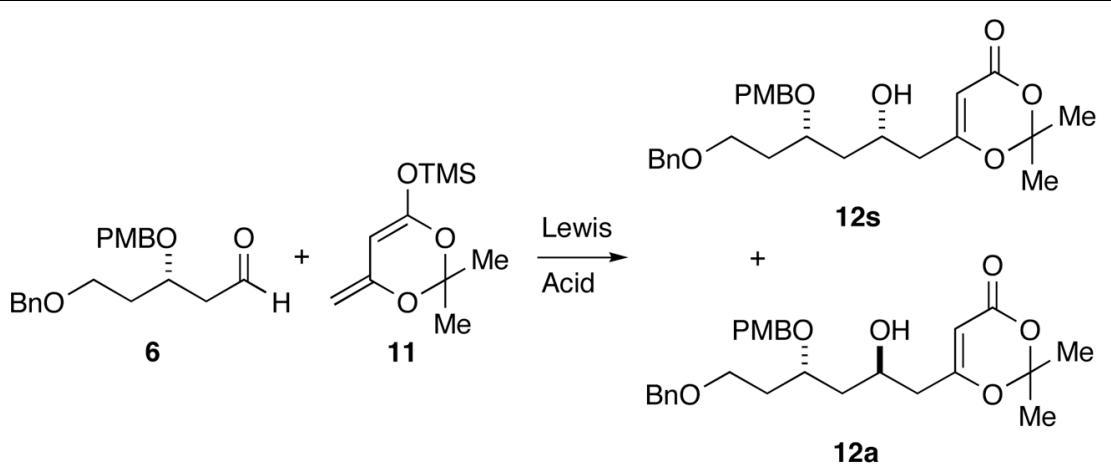

\begin{tabular}{lllll}
\hline & Lewis acid & ligand & Yield (\%) & Selectivity (12a:12s) \\
\hline 1 & $\mathrm{BF}_{3} \cdot \mathrm{OEt}_{2}$ & - & 90 & $1: 1$ \\
2 & $\mathrm{Me}_{2} \mathrm{AlCl}$ & - & 45 & $1.3: 1$ \\
3 & $\mathrm{TiCl}_{4}$ & - & 61 & $1.5: 1$ \\
4 & $\mathrm{Ti}(\mathrm{O}-\mathrm{Pr})_{4}$ & - & 0 & - \\
5 & $\mathrm{Ti}(\mathrm{O} i-\mathrm{Pr})_{2} \mathrm{Cl}_{3}$ & - & 82 & $2.0: 1$ \\
6 & $\mathrm{Ti}(\mathrm{O} i-\mathrm{Pr})_{2} \mathrm{Cl}_{2}$ & - & 89 & $3.3: 1$ \\
7 & $\mathrm{Ti}(\mathrm{O} i-\mathrm{Pr})_{3} \mathrm{Cl}$ & - & 21 & $2.4: 1$ \\
8 & $\mathrm{Ti}(\mathrm{O} i-\mathrm{Pr})_{4}$ & $(S, S)-(+)-\mathrm{TADDOL}$ & 28 & $1: 1$ \\
9 & $\mathrm{Ti}(\mathrm{O} i-\mathrm{Pr})_{2} \mathrm{Cl}_{2}$ & $(R, R)-(-)-\mathrm{TADDOL}$ & 64 & $1: 5$ \\
10 & $\mathrm{Ti}(\mathrm{O} i-\mathrm{Pr})_{2} \mathrm{Cl}_{2}$ & $(-)-13$ & 80 & $1: 2.1$ \\
11 & $\mathrm{Ti}(\mathrm{O} i-\mathrm{Pr})_{4}$ & $(+)-13$ & 95 & $8.6: 1$ \\
12 & $\mathrm{Ti}(\mathrm{O} i-\mathrm{Pr})_{4}$ & & & $1: 10$ \\
\hline
\end{tabular}

Org Lett. Author manuscript; available in PMC 2008 September 22. 